INTERDISCIPLINARIA ARCHAEOLOGICA NATURAL SCIENCES IN ARCHAEOLOGY

Thematic Review

\title{
Exotic Spices in Flux: Archaeobotanical Material from Medieval and Early Modern Sites of the Czech Lands (Czech Republic)
}

\author{
Michal Preusz $^{a^{*}}$, Kateřina Kodýdkováa ${ }^{\mathrm{a}}$ Petr Kočár ${ }^{\mathrm{b}}$, Zdeněk Vaněček ${ }^{\mathrm{c}}$ \\ aUniversity of South Bohemia, Faculty of Science, Laboratory of Archaeobotany and Palaeoecology, Branišovská 31 , 37005 České Budějovice, \\ Czech Republic \\ ${ }^{b}$ Institute of Archaeology of the Czech Academy of Sciences of the Czech Republic, Letenská 123, 118 00, Prague, Czech Republic \\ 'Palacký University Olomouc, Faculty of Science, Department of Analytical Chemistry, 17. listopadu 12, 77146 Olomouc, Czech Republic
}

\section{ARTICLE INFO}

\section{Article history:}

Received: $23^{\text {rd }}$ April 2015

Accepted: $14^{\text {th }}$ December 2015

\section{Key words:}

exotic spices

luxury food

imports

New World

Asia

Europe

trade routes

consumer society

archaeobotany

macro-remains

\begin{abstract}
$A B S T R A C T$
According to the core-periphery model of economic geography, the Medieval and Early Modern Czech lands can be called a semi-periphery. They are located in a hilly part of central Europe, in the shadows of the world's naval powers. Over the centuries this location has greatly influenced their domestic consumer society, in many ways lacking in self-sufficiency and often having to rely on the import of foreign and exotic goods through a global sales network; amongst these rare goods were different kinds of spices. These imported species, specifically assimilated, became not only an important part of the diet, but also a symbol of luxury. This paper presents the current state of research into exotic spices that have been discovered in archaeological contexts in today's Czech Republic, and illustrates their importance for the interpretation of trade in exotic goods and the historical socio-cultural level of local consumers.
\end{abstract}

\section{Introduction}

The remains of Medieval and Early Modern life can be seen at every step in the Czech countryside, there being a large number of Romanesque and Gothic castles, monasteries, towns and villages, which have later been rebuilt in the spirit of modernizing styles. Under these many reconstructions we can capture yet another dimension, from which we can gain archaeological, archaeobotanical and archaeozoological data. These can significantly enhance our "on-the-surface" awareness and in a unique way extend our knowledge about the everyday life, trade, diet and other activities of historical societies. From this perspective, the findings of thousands of plant macro-residues can indicate the specific relationships

*Corresponding author. E-mail: preusz.michal@gmail.com between plants and historical actors in the past, as well as represent archives of information about the paleoecology of surveyed sites.

Even in these archives it is often possible to find unusual findings: "curiosities". Among the broad spectrum of findings of plant macro-remains that are of exotic origin, it can be determined that Czech people only had access to them via trans-regional trade. These specific taxa included spices that had been imported into the central European environment from Asia, and later on some from the New World (Figure 1). Europeans were fascinated not only by their exoticism but also their specificity, other-worldly taste and medicinal properties. Archaeobotanical finds of spices are an indication of the level of trade in exotic goods, its assimilation into different social environments and the level of luxury that was linked to exotic spices. Also, easily overlooked, local findings suddenly overlap into a global 


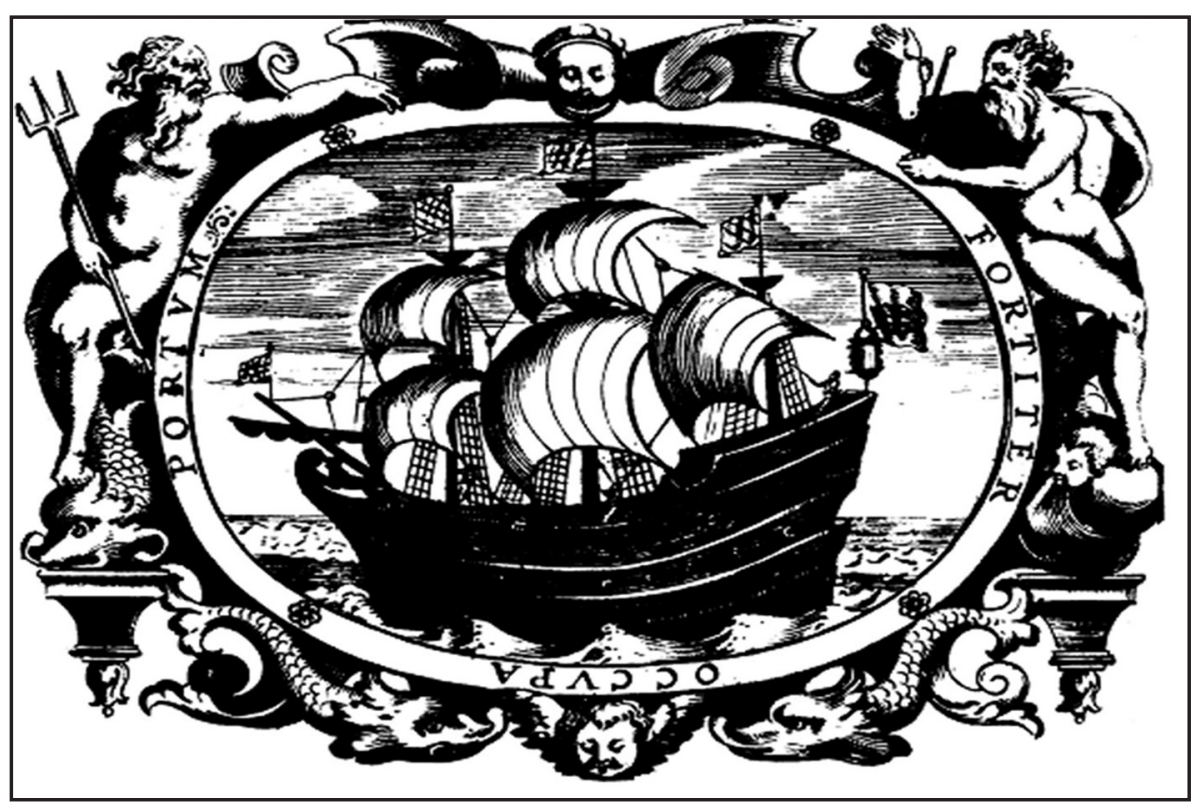

Figure 1. Trade ship as a symbol of the import of exotic plants to Europe on the cover of an early modern herbarium (Castore Durante, Herbario Nuovo, Roma 1567).

dimension, showing the mechanisms in which the consumers of central European society operated (Orser 2008).

\section{Materials and methods}

The data used in this article come from published Czech archaeobotanical research and also from unpublished data belonging to the authors of this article. Though in the articles the researched methods were not always discussed, most of the materials were processed by wet sieving with minimum sizes of mesh from 0.25 to $0.4 \mathrm{~mm}$. Only one case of dry sieving was mentioned: being used to process dry material from the vault infill from Vladislav's Hall in Prague (Table 1).
Findings of spices clearly dominate in sediments from cesspits, followed by other wet contexts such as wells, water trenches and wet waste layers. Other findings come from dry contexts such as vault infills. In the series of published results, the archaeological context was not always clearly described, making it impossible to interpret the current situation (Figure 2).

Archaeobotanical analyses answer many environmental and also archaeological questions. They bring insights to the reconstruction of landscapes in specific time periods and show changes in vegetational cover; for the archaeologist, they can reconstruct human impact and show the structure of settlement areas. Macro-remains also provide information about the origin and distribution of plant species, as well

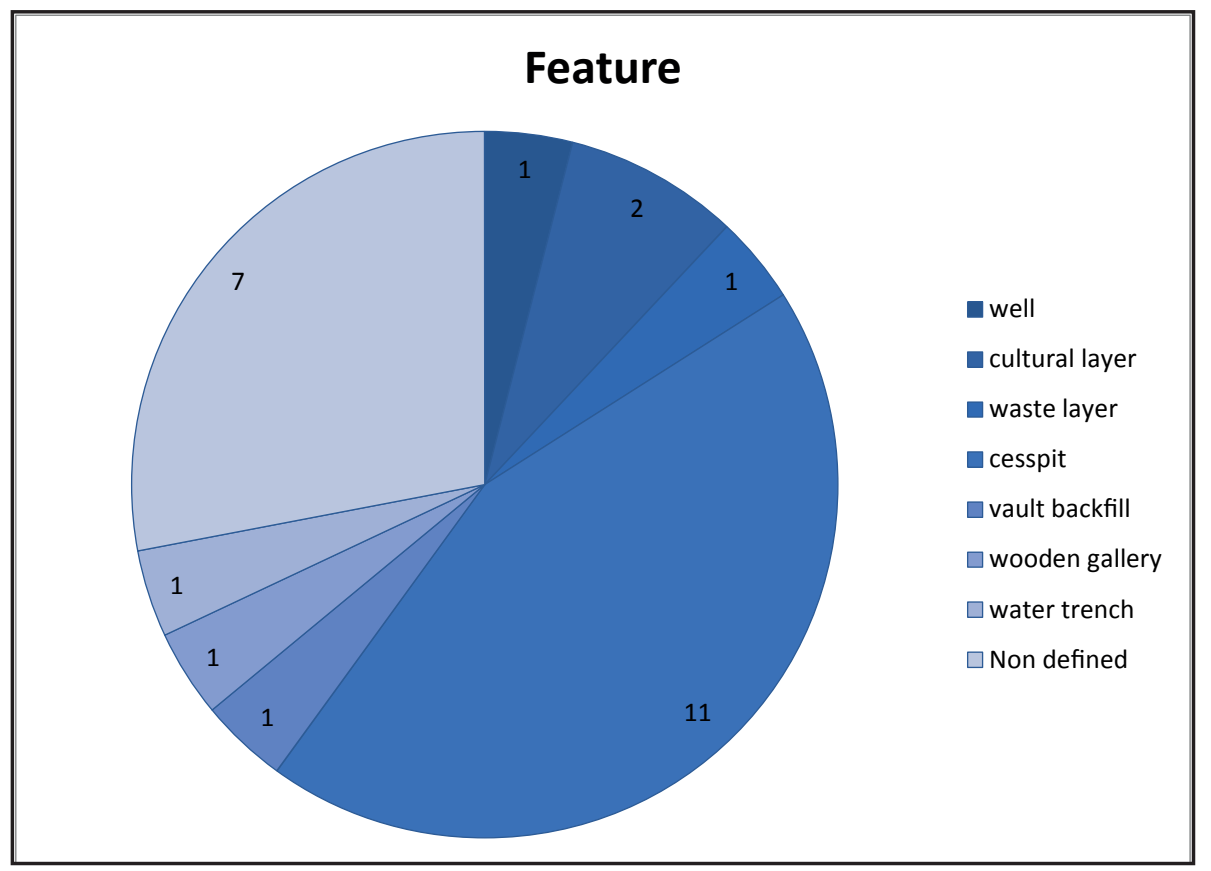

Figure 2. Findings of macro-remains of spices according to archaeological situations (M. Preusz). 
Piper nigrum

Pimenta dioica

Myristica fragrans

Elettaria cardamonum

Capsicum annuum

State of preservation

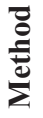

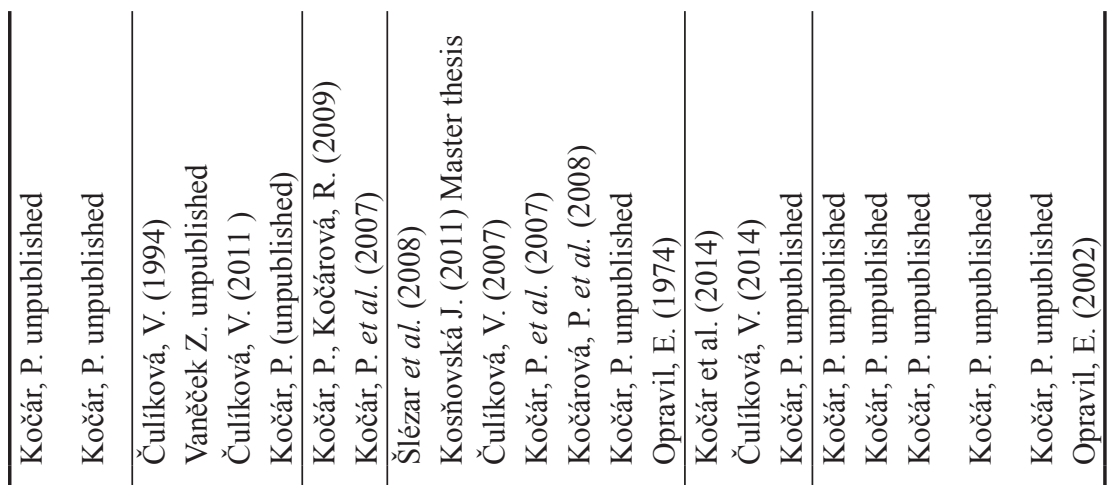

$x$

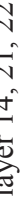

离离

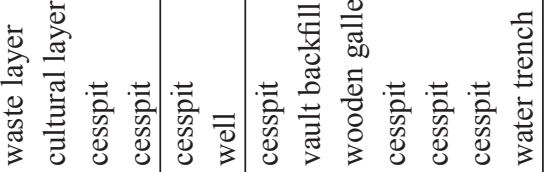

\begin{tabular}{l|lll}
$\overrightarrow{0}$ & $\overrightarrow{0}$ & $\overrightarrow{0}$ & $\overrightarrow{0}$ \\
0 & 0 & 0 \\
0 & 0 & 0 & 0 \\
0 & 0 & 0 & 0 \\
0 & 0 & 0
\end{tabular}

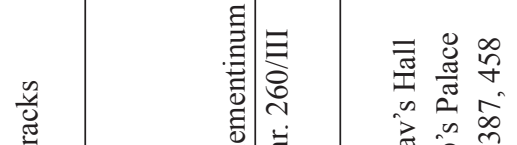


as changes in the assortment of cultivated plants in past cultures. And lastly, but not least, they provide information regarding human diet and imported species.

During macro-remains analyses, mostly the seeds of flowering plants are separated, but there may also be fruits, buds, pieces of leaves and conifer needles, twigs, wood and other parts of plants. With the addition of micro-remains analyses (pollen, phytolits), together with the archaeological results, they provide a more complete site interpretation.

In the case of spices, we must start with two assumptions. First of all, although many seeds/fruits are used as spices, they are often turned into different forms (ground, shredded, etc.); secondly, even some leaves and other soft parts of plants are used for the same purpose. These pulverized parts of plants do not preserve well in any kind of sediment. On the other hand, finds of whole seeds of species from the Mediterranean region, or of other origins, can support the idea of the cultivation of many of these species within the region of the Czech lands, as this corresponds with written sources (i.e. Mattioli 2005).

\section{The state of contemporary research of spices}

The presence and range of varieties of spices in the Middle Ages and Modern times used to be studied purely from written records. One of the oldest available sources is Claret's lexicon, containing old Czech-Latin lists of spices that were used in the latter half of the $14^{\text {th }}$ century (Flajšhans 1926; 1928). During the $15^{\text {th }}$ century, new medicine tracts and herbariums became available. Of the greatest significance for the Czech lands is the herbarium written by Mattioli from 1596 (Mattioli 2005) and the medical tract "Lékařská pojednání” by Křištan from Prachatice (Tichá 1975). With respect to the consumption of spices, there also belong some Medieval and early Modern cookbooks and recipes (Zíbrt 2011). Less available sources are the receipts and expenses for spices that used to be recorded by the administrators of aristocratic courts (Hrdlička 2000). Unfortunately, there is no such rich basis of written records for the common urban environment: only scarce lists of merchandise, or the records of prices of spices on city markets, are available (Winter 1892). Other sporadic evidence of spices comes from travelogues. Compared to written sources, even less attention has been paid to other kinds of records - iconographies, artefacts and ecofacts.

The first attempts at interpreting plant fossils found during archaeological excavations in Czech lands took place in the second half of the $19^{\text {th }}$ century. These are associated with the names Lüssner $(1859,1865)$ Jeitteles (1872) and later with Rzehak (1904), Fietz (1941) and Dohnal (1958). Actual systematic archaeobotanical analyses started simultaneously with the development of medieval archaeology (Smetánka, Žegklitz 1990). In 1961, Emanuel Opravil established archaeobotany as a scientific discipline in the Czech Republic. Since that time he has published over 300 articles concerning plant macro-remains analyses, many of them

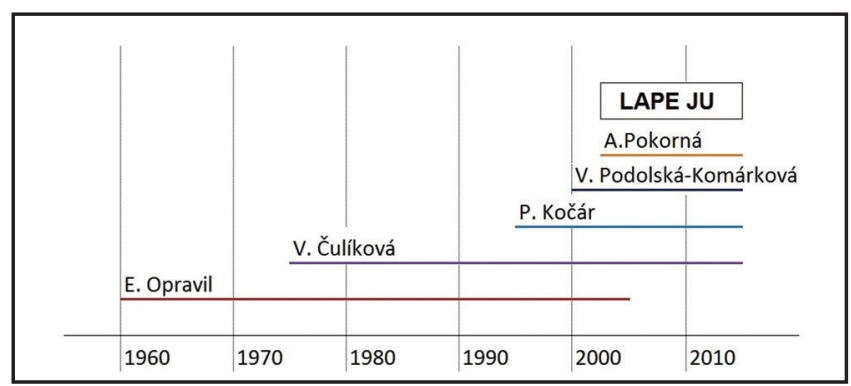

Figure 3. Timeline showing the names of archaeobotanists (Lape Alexandra Bernardová, Tereza Šálková, Jitka Kosňovská, Kateřina Kodýdková, Michaela Divišová, and Zdeněk Vaněček).

with identified spice species. In the 1970s, Věra Čulíková processed a huge amount of material from the Medieval town of Most. In the 1990s, Petr Kočár was engaged in archaeobotany and, shortly after 2000, The Laboratory of Archaeobotany and Paleoecology was founded with a number of young archaeobotanists, some of whom are specialized in the Middle Ages and Modern times (Figure 3). Although the base "corps" of archaeobotanists is gradually growing, there is still no complete database of all their research.

\section{The origin of spices}

The spices and aromatic plants determined from archaeobotanical finds from the Czech Republic have different origins (e.g. Asia, Europe, America). In this study, only species that used to be imported to the Czech lands as luxury goods are presented in detail: the Asian spices cardamom (Elettaria cardamomum), nutmeg (Myristica fragrans), black pepper (Piper nigrum) and the spices pepper (Capsicum annuum); and allspice (Pimenta dioica) from the New World.

\section{Luxurious spices from Old Asian World}

The package of Asian spices can be divided into two parts. The first includes species that were imported to the Mediterranean and central Europe and assimilated - lovage (Levisticum officinale) and basil (Ocimum basilicum). The second part is represented by species that grow solely in tropical regions and whose distribution was dependent on their import. This group includes black pepper (Piper nigrum), nutmeg (Myristica fragrans) and cardamom (Elettaria cardamomum).

\subsection{Black pepper (Piper nigrum)}

Piper nigrum is a perennial flowering plant with alternate, entire leaves up to $10 \mathrm{~cm}$ long and $6 \mathrm{~cm}$ across. On supporting trees it can grow up to $4 \mathrm{~m}$ high. Black pepper is native to southwest India. The fruits of Piper nigrum are drupes, socalled peppercorns. When they are fully matured they are dark red. Different colours of peppercorns are derived from 
the time of their harvest and subsequent processing. Black pepper comes from unripe drupes that were fermented and dried in the sun. Green pepper is from unripe and dried drupes, while white pepper is from fully ripe and dried drupes. Red peppers are drupes harvested fully ripe and immediately pickled in brine. Other types or colours of pepper usually refer to another plant species (Vaughan, Geissler 2009, 146).

The fall of the Roman Empire led to the decay and restructuring of established business networks between Europe and India, sensitive as they were to socio-political change. Quite early on, Medieval society began to covet the resumption of supplies of spices as it had been in Roman times. The continual return to the traditional ancient knowledge of pepper in Greek and Roman culture serves as evidence of this, meaning not only the acceptance of its knowledge, but also some of its errors. Roman pharmacologist Dioscorides (40-90 AD) incorrectly merged long pepper and black pepper as one species. This error was then subsequently reproduced many times - by Pliny in the $1^{\text {st }}$ century, Galenus in the $2^{\text {nd }}$ century, Isidor of Seville (560-636 AD) in the $7^{\text {th }}$ century, Avicenna (930-1037 AD) in the $10^{\text {th }}$ century and so on (Toussaint-Samat 2008).

From the $12^{\text {th }}$ century onwards, the possibility for long cruises in the Mediterranean re-opened and the spice trade was soon taken over by the Venetians. In the $14^{\text {th }}$ century they imported pepper, wax, sandalwood and ginger from India to the east, and in return they exported metal and other finished products. In the first half of the $15^{\text {th }}$ century Venetians had 3300 Argosies (large merchant ships). This huge commercial power annually brought from Alexandria 600 tons of pepper along with other exotic commodities. Due to these vast amounts, there appeared many city officials who specialized exclusively in pepper (Ackroyd 2010).

The rise of social groups of specialists mirrored the social and cultural tensions in the city of Venice's economic centre, which quickly realized that fashion and the introduction of new products represented the most important concepts in its trade. Pepper was one of the items imported from great distances, signifying high risks, but also high profits from its eventual sale.

The spice trade came to be dominated by rational calculation and abstract relationships of credit and exchange, which began to create a new kind of society: a society of goods for sale and consumers to buy them. It also brought Venice to the setting up of banks and the formation of national debt. Other trading groups in other states began to react to the profitable business being conducted in Venice - and soon specialists were appearing everywhere: "the Pepperers" in Britain, "Pfeffersacke" in German-speaking countries, and "Poivrier" in France. The expansion of pepper during the $13^{\text {th }}$ and $14^{\text {th }}$ century in Europe is confirmed by the findings of pepper from the Hanseatic towns (Karg 2007, 27, Table 5).

During the $15^{\text {th }}$ century the European trade with black pepper was slowed down by the expansion of Ottoman Empire, which initially blocked land routes to the Middle East, and then conquered Egypt and occupied the northern coast of Africa. The Mediterranean region became a battleground between Christians and Muslims. It was the beginning of the search for alternative routes. The Portuguese had circumnavigated Africa and began to import pepper on their merchant "nao", or "nau", ships (carracks). The so-called "Pepper wrecks" that are being discovered on the route from Lisbon to Calicut (the "City of Spices" now known as Kozhikode) (Figure 4) are a unique testament to the dogged pursuit of modern retailers to regain the lost glory of the lucrative spice trade (Alves 2011; Castro-Fonseca-Wells 2010). The Indian Ocean once again became a theatre of conflict for the powerful European states that sought to dominate the market. For this purpose many "East Indian" companies were established, such as the Dutch India Company (VOC) or the East India Company (EIC) (Flatman-Staniforth 2006, 183-186). Findings of wrecks of merchant ships are a testimony to a nation's global social, economic, political, as well as its military, influence. Moreover, one unexpected result of the search for new sea

Figure 4. Reconstruction of the wreck of a portuguese nao (nau) ship or carrack, used to transport pepper, a so-called "Pepper wreck" (according to Castro-Fonseca-Wells 2010, 29, Figure 7).

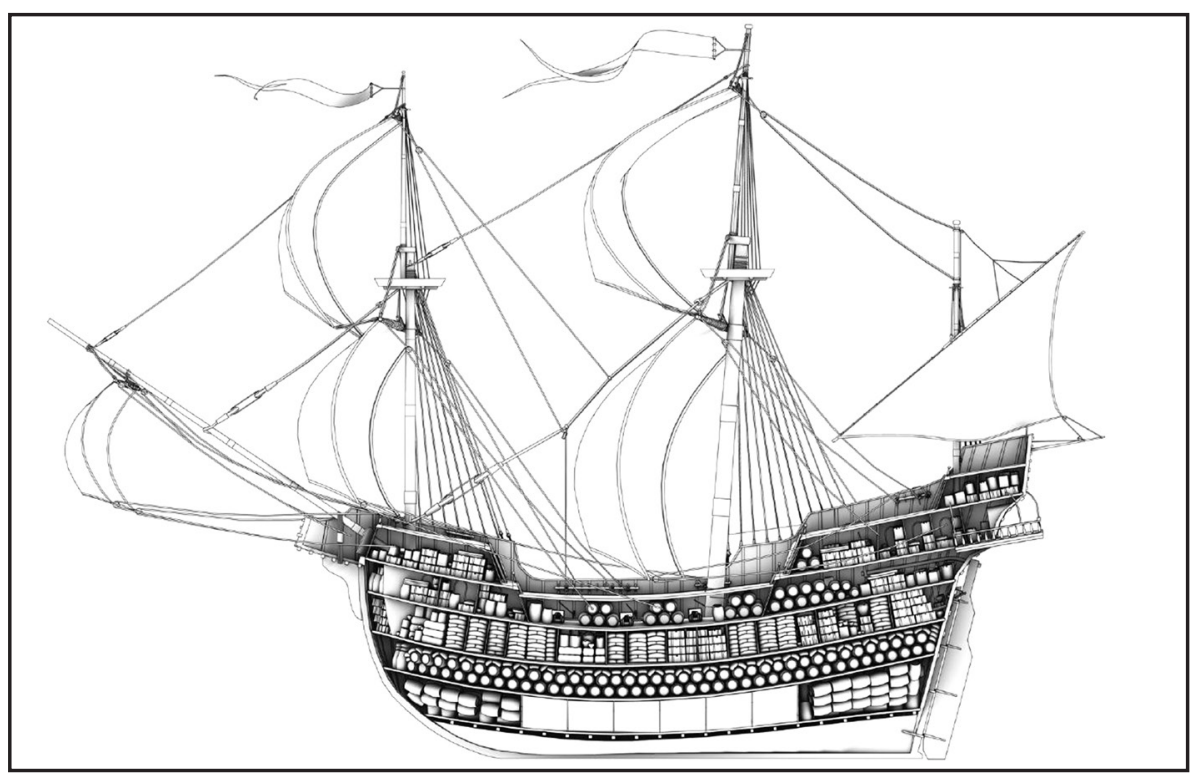




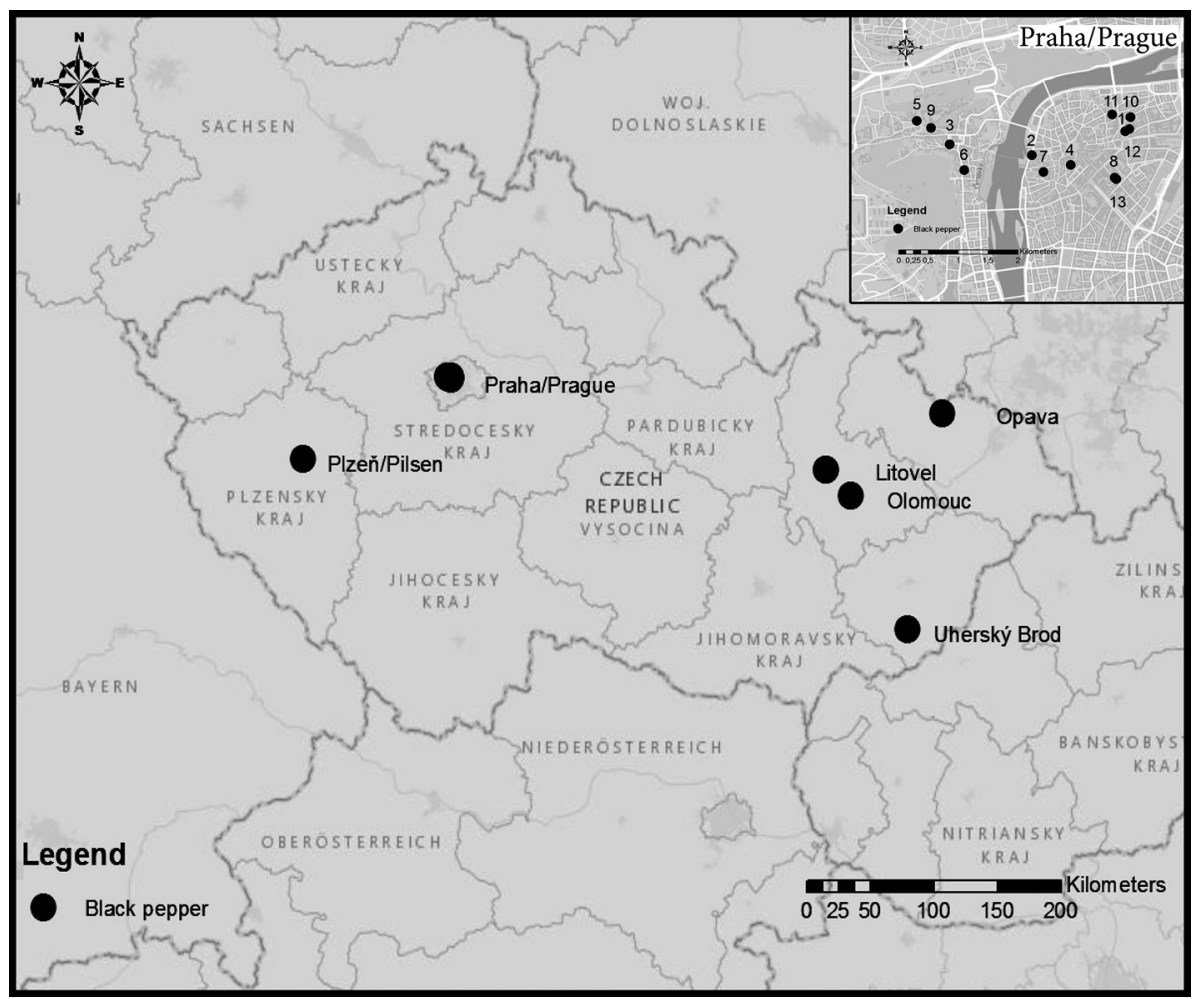

Figure 5. Map of archaeobotanical findings of Piper nigrum in the Czech Republic and historical core of Prague: 1. Republiky sq., barrack of Jiří z Poděbrad; 2. Křižovnická st., Klementinum; 3. Malostranské sq., no. 260/III; 4. Melantrichova st.; 5. Hradčany, Archbishop's Palace; 6. Karmelitská st., no. 387, 458; 7. Liliová st., no. 248; 8. Národní st. "Copa"; 9. Thunovská st., no. 192/III; 10. Truhlářská st., no. 16/1147; 11. Dlouhá st., no. 721/I; 12. Republiky sq., barrack of Jiř́i z Poděbrad; 13. Národní st. "Copa" (M. Preusz).

routes to India was the discovery of the New World, which later reduced the socio-political importance of the traditional spice routes.

Evidence of black pepper in the Czech lands has come from 19 localities. The oldest finds are from the $13^{\text {th }}$ century from Litovel and Prague (Figure 5), other Medieval finds coming from Olomouc and Opava. Early Modern finds of pepper are from Prague, Uherský Brod and Plzeň (Figure 6a). It is usually hard to distinguish between black and white peppers from archaeological situations. The skin of drupes may have become removed due to the conditions in the sediment and thus lead to an incorrect determination as being black pepper. But there are also finds of complete drupes - white pepper: for example, in Olomouc (Vaněček unpubl.), Opava (Čulíková 2011), and Prague (Čulíková 2014).

\subsection{Nutmeg (Myristica fragrans)}

Myristica fragrans is an evergreen tree indigenous to the Moluccas of Indonesia. This dioecious tree is usually 5-13 m tall and has alternately-arranged, dark-green leaves. The flowers are bell-shaped and pale yellow. Female trees produce pear-shaped fruit yellow in colour. The seed is brown, about $2-3 \mathrm{~cm}$ long and $2 \mathrm{~cm}$ wide, and is covered by a red aril (seed pod). The seeds are the source of nutmeg, and the dried and ground aril provides the spice called mace (Vaughan, Geissler 2009, 148).

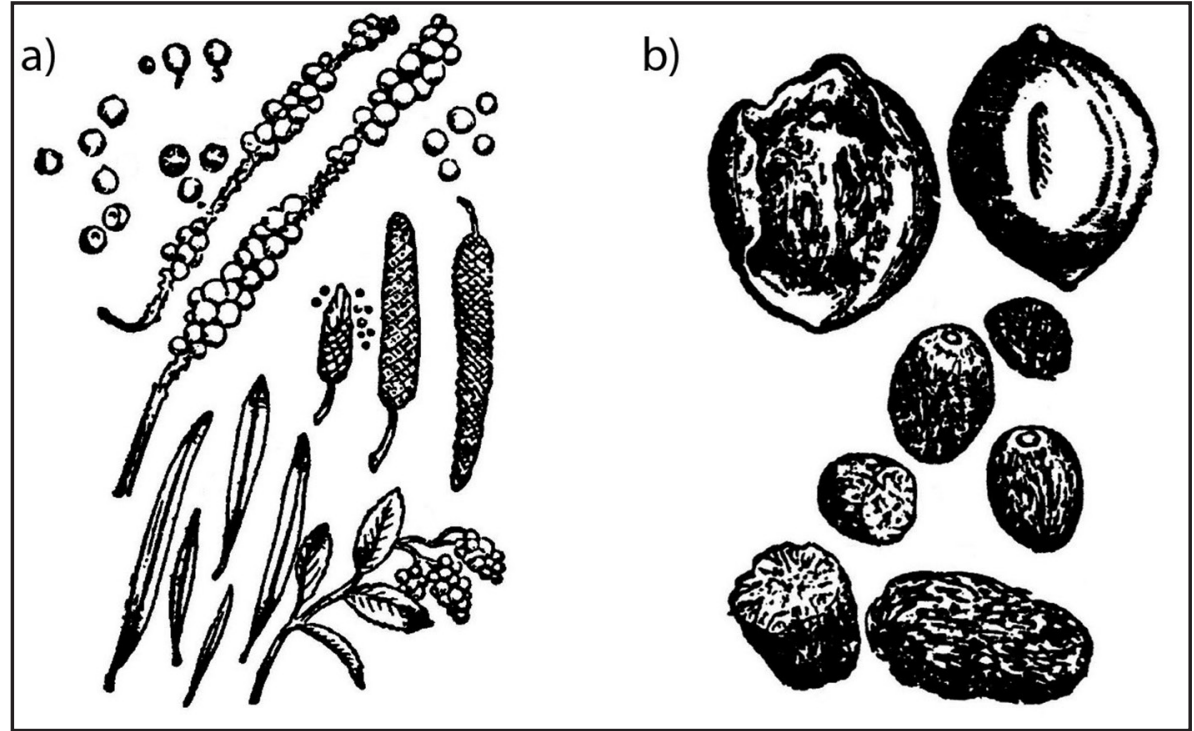

Figure 6. Spices imported from Asia: a) black pepper (Piper nigrum); b) nutmeg (Myristica fragrans; Mattioli, 2005). 
Nutmeg was introduced to Europe by Arabian merchants. References from the Mediterranean region date back to the $6^{\text {th }}$ century (Jirásek 1958). During the Middle Ages, trade with nutmeg and many other spices and goods was controlled by the Venetians (Kybal, Kaplická 1988). The price for this spice was extremely high; not even in Modern times has the price been lower. The Molucca Islands were discovered by the Portuguese in 1514 (Davidson 2002) and in 1602 its monopoly was taken over by the Dutch Indian Company, so prices for nutmeg remained high. The monopoly was crushed when the French gained seedlings and started their own cultivation of nutmeg in other areas (Polívka 1908). The English had a big hand in expanding these areas in the $18^{\text {th }}$ and $19^{\text {th }}$ centuries (Davidson 2002).

Nutmeg was transported to the Czech lands from Italy, across Germany and Austria (Kybal, Kaplická 1988). In Mattioli's herbarium two types of nutmeg are distinguished: the first called "male", was oblong in shape, whereas the other was round and considered more effective as a spice. Nutmeg was used in the kitchen as a spice and also in medicine as a drug to heal head and stomach ache (Mattioli 2005, 222224) (Figure 6b). It was usually ground and mixed with red wine. Nutmeg was also often misused for its intoxicating effects (Beneš et al. 1998).

Archaeological findings of nutmeg are quite rare (Figure 7). The first and oldest find of nutmeg in the Czech lands is from Beroun and dates back to the $14^{\text {th }}$ century (Čulíková 1994). The second find is from the vault backfill from Vladislav's hall in Prague Castle (Kosňovská 2011) and is dated to the $16^{\text {th }}$ century. Other finds from Europe are from Slovakia (Bratislava) (Hajnalová 1985), from Scotland
(Paisley Abbey) (Dickson 1996), and Poland (Latałowa et al. 1998).

\subsection{Cardamom (Elettaria cardamomum)}

Elettaria cardamomum is an up-to-5-metres-tall perennial herb from the Zingiberaceae family. It is native to the monsoon forests of South India and Sri Lanka. The fruits are capsules with several dark seeds. They are usually harvested before they are fully ripe. To preserve the spice essence, the whole capsules are cut and then slowly dried (Vaughan, Geissler 2009; 148). As the Piper nigrum was known as the "King of Spices", cardamom is often referred to as the "Queen of Spices" for its pleasant mild aroma and unique taste (Prabhakaran Nair 2011). In India, cardamom was an important part of the economy and also a part of the Indian Ayurvedic medicinal tradition and cuisine (Kybal, Kaplická 1988).

The first written records of the transport of cardamom to Greece can be found in the work of Theophrastus which date back to the $4^{\text {th }}$ century BC. Both Greeks and Romans used cardamom as the main essence for perfumes: not only for its unique aroma, but also for its aphrodisiac effect. By 1000 $\mathrm{AD}$, cardamom was being transported mostly by Arabian merchants to other Mediterranean countries and further into Europe. Even the Vikings were aware of cardamom after their voyages to Constantinople around 1000 AD (Kybal, Kaplická 1988).

In the Czech lands, cardamom has been definitely known since Medieval times. It was said that cardamom was grown in Calicut, Malabar and Java (Kybal, Kaplická 1988). Mattioli claims that it was transported to Europe through

Figure 7. Map of archaeobotanical findings of Myristica fragrans in the Czech Republic and historical centre of Prague: 1. Prague Castle, Vladislav's hall (M. Preusz).

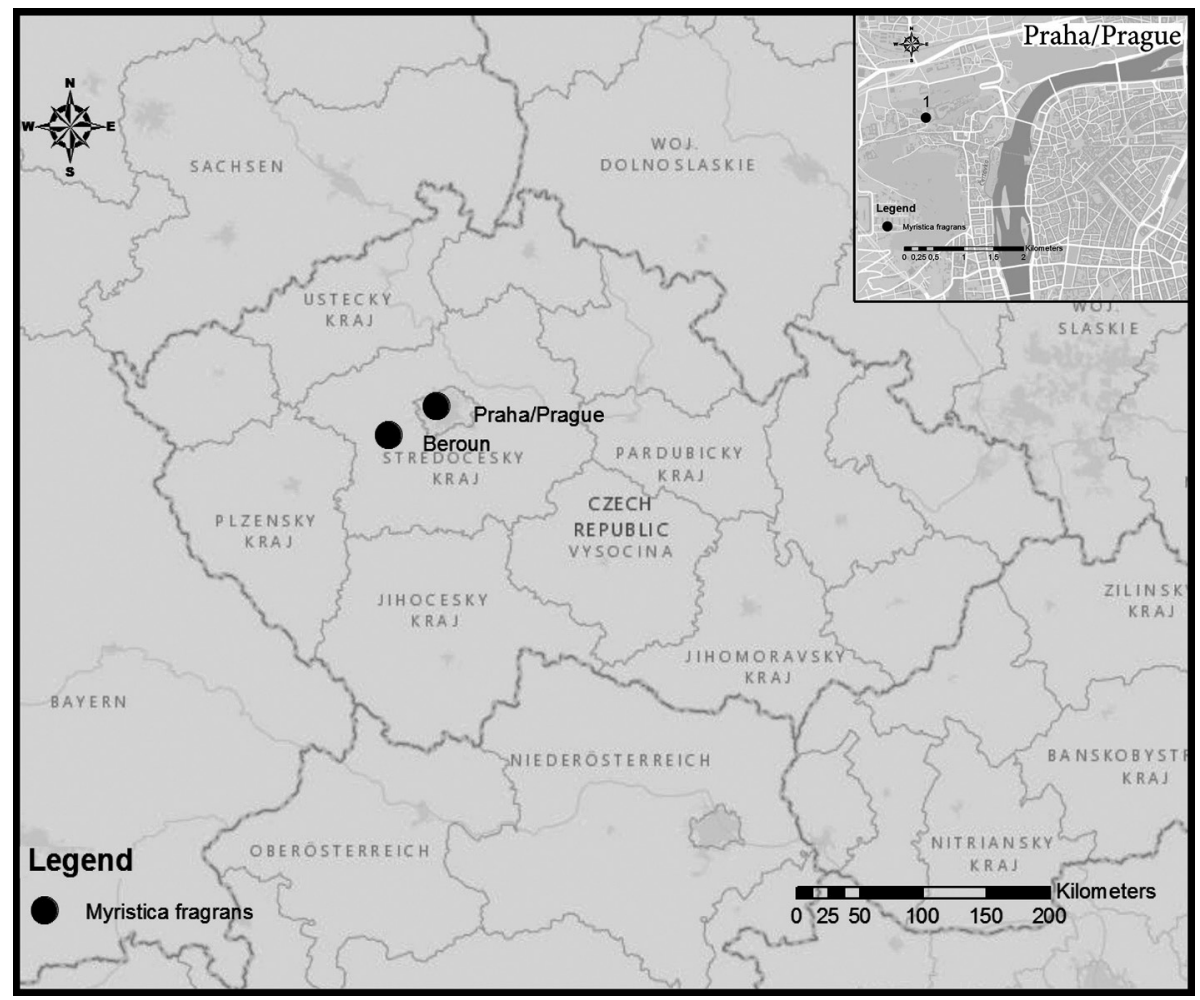




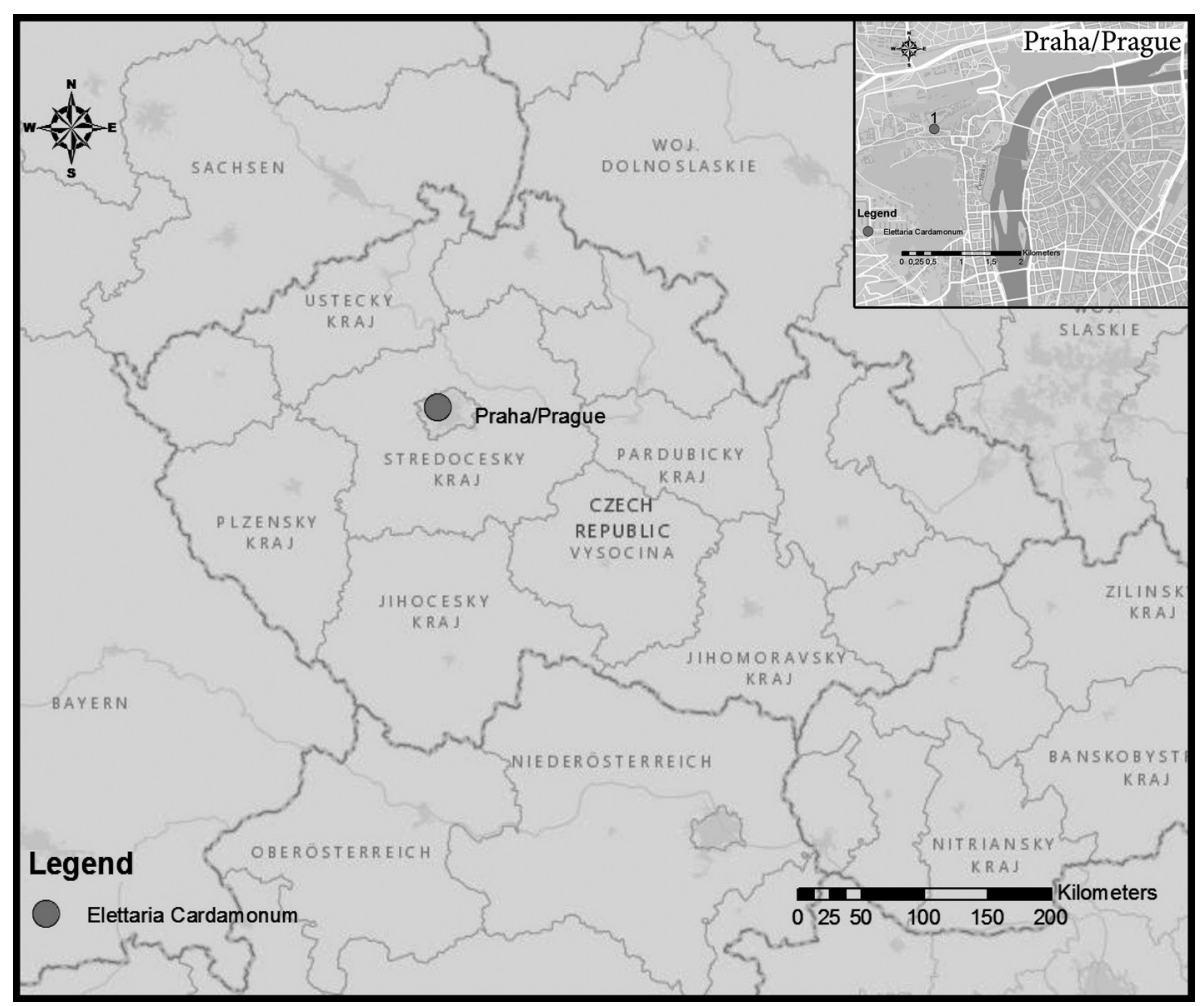

Figure 8. Map of archaeobotanical findings of Elettaria cardamomum in the Czech Republic and the historical centre of Prague: 1. Thunovská st., no. 192/III (M. Preusz).

Alexandria and in three different variants - small, medium and large (Figure 9). All of them were called cardamom, but each corresponds to a different plant species. According to Mattioli, the largest type of cardamom was also called

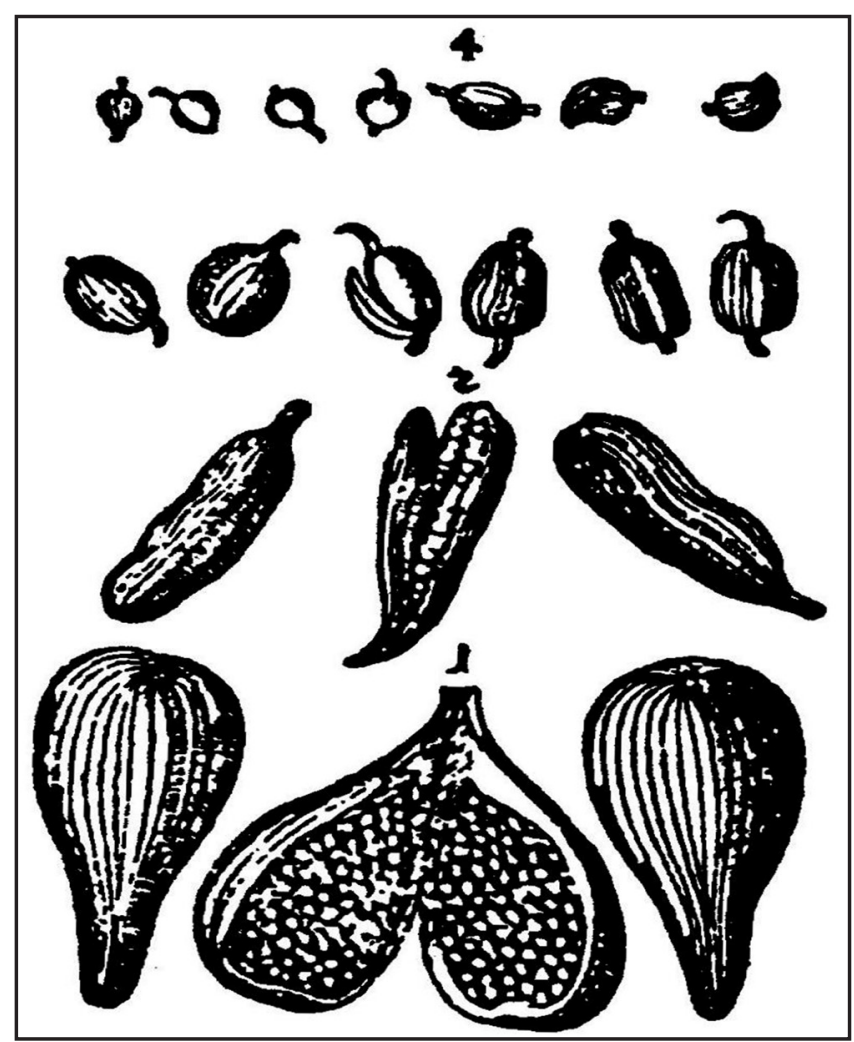

Figure 9. Imported spices from Asia: True Cardamom (Elettaria cardamomum; Mattioli 2005).
Grana Paradisi in Czech lands, due to its unique taste and smell (Mattioli 2005, 413-416). The name actually refers to Aframomum melegueta, which was used as a substitute for cardamom (Vaughan, Geissler 2009; 148,150)

As cardamom was a valued spice, archaeobotanical finds from Europe are mostly connected with archaeological situations that indicate places of higher social status. The finds in Germany vary from the $12^{\text {th }}$ century to Modern times (e.g. Alsleben 1991; Hellwig 1997; Wolf 1997; Paetzold 1998; Wiethold 1999). Finds from Poland are declared as being from Gdansk (Badura 2011). Seeds found in two latrines dated to the $15^{\text {th }}-17^{\text {th }}$ century and located in the wealthier district of the town can also be connected to people from the upper classes.

The first and only find of six seeds of cardamom in the Czech Lands comes from Prague (Figure 8). A macro-remains analysis was conducted on very rich sediments from a cesspit dated to the turn of the $17^{\text {th }}$ to $18^{\text {th }}$ century (Čulíková 2014). The cesspit belonged to a college of the Theanines order. It contained faeces and waste from the dispensary of the monastery. With over 210 species and 110000 diaspores, including Elettaria cardamomum, Piper nigrum, Capsicum annuum, Nicotiana tabacum and many others, it represents the richest set of finds from Early Modern times within the whole of Europe.

\section{Luxurious spices from the New World}

The extent of world trade in spices grew to global proportions in the late $15^{\text {th }}$ century. The voyage of Christopher Columbus across the Atlantic to the shores of the New World opened up new trade routes for commodities, among which exotic 
plant species formed an important part. These neophytes were imported to the Czech lands far more slowly than to the coastal countries of Europe. Finds of American species dated to the $16^{\text {th }}$ century are thus among the rarities - in central Europe they became a symbol of the new Renaissance way of life.

\subsection{Allspice (Pimenta dioica)}

Pimenta dioica, known as allspice, is native to Central America. It occurs in the Antilles, Cuba and southern Mexico, and probably in Haiti and Costa Rica (Adams 1972). This small tree is 6-12 $\mathrm{m}$ high; the trunk is smooth and the leaves are large, dark green, pointed and leathery. The flowers are white and arranged in pyramidal cymes. Fruits are berry-like drupes with two seeds. They are harvested unripe, since they lose aroma when mature (Vaughan, Geissler 2009; 150). Allspice was known and used by the Aztecs, who used it for spicing their chocolate (Kybal, Kaplická 1988). It was introduced to Europe shortly after the discovery of the America, but it is unknown from renaissance herbariums. The first records come from the beginning of the $17^{\text {th }}$ century (Polívka 1908). The biggest importers were Spaniards and, according to written sources, allspices became rather popular in European cuisines (Greig 1996). It was used to spice and also preserve meat, in sauces and marinades, and it also had its application in cosmetics. The name Allspice comes from the idea that the aroma and flavour resembles clove, cinnamon, and nutmeg, and some authors even say also pepper (Kybal, Kaplická 1988).

In the Czech lands there are two finds of allspice, both in the capital city Prague (Figure 10). Two seeds were discovered in a well in Melantrichova street, in which the sediment was dated to between the $15^{\text {th }}$ century and 1615 (Kočár et al. 2007); the other find comes from a cesspit in Dlouhá street and it was dated to the $17^{\text {th }} / 18^{\text {th }}$ century. These finds are quite unique, since there are only two other published finds of allspice, both dated to the $18^{\text {th }}$ century. One is from London (Giorgi 1997), and the other is from Gdansk (Badura 2003).

\subsection{Pepper (Capsicum annum)}

Capsicum annuum is, in suitable conditions, a perennial plant of the Solanaceae family. It has been cultivated in Central America since ancient times. Peppers were introduced to Europe shortly after the discovery of the New World and were imported from Haiti (Kybal, Kaplická 1988, 78).

Fields of Capsicum annuum are mentioned in Moravia in 1583 (Kavina 1951, 107) and the French botanist Carolus Clusius claimed that he had seen extensive planting of this spice in fields around the city of Brno in 1585. In the $16^{\text {th }}$ century, different names were used in the Czech lands, all of them expressing a touch of exoticism: "Pepř indiánský" (Indian pepper), or "Pepř turecký" (Turkish pepper) (Figure 11). Peppers were grown for kitchen use and also as ornamental plants. It used to be grown in tubes so it could be moved indoors in case of cold weather. They were eaten fresh or dried, according to the Spanish custom. In medicine they were used against dropsy (Mattioli 2005, 406 - 407).

The spread of peppers in the central European environment is reflected in the archaeobotanical finds from Early Modern archaeological contexts. So far, seeds of peppers have been found at four urban localities (Figure 12). Finds of seeds from Brno and one base of a pepper berry from Prague are dated to the $16^{\text {th }}$ century. Findings from the mining town of

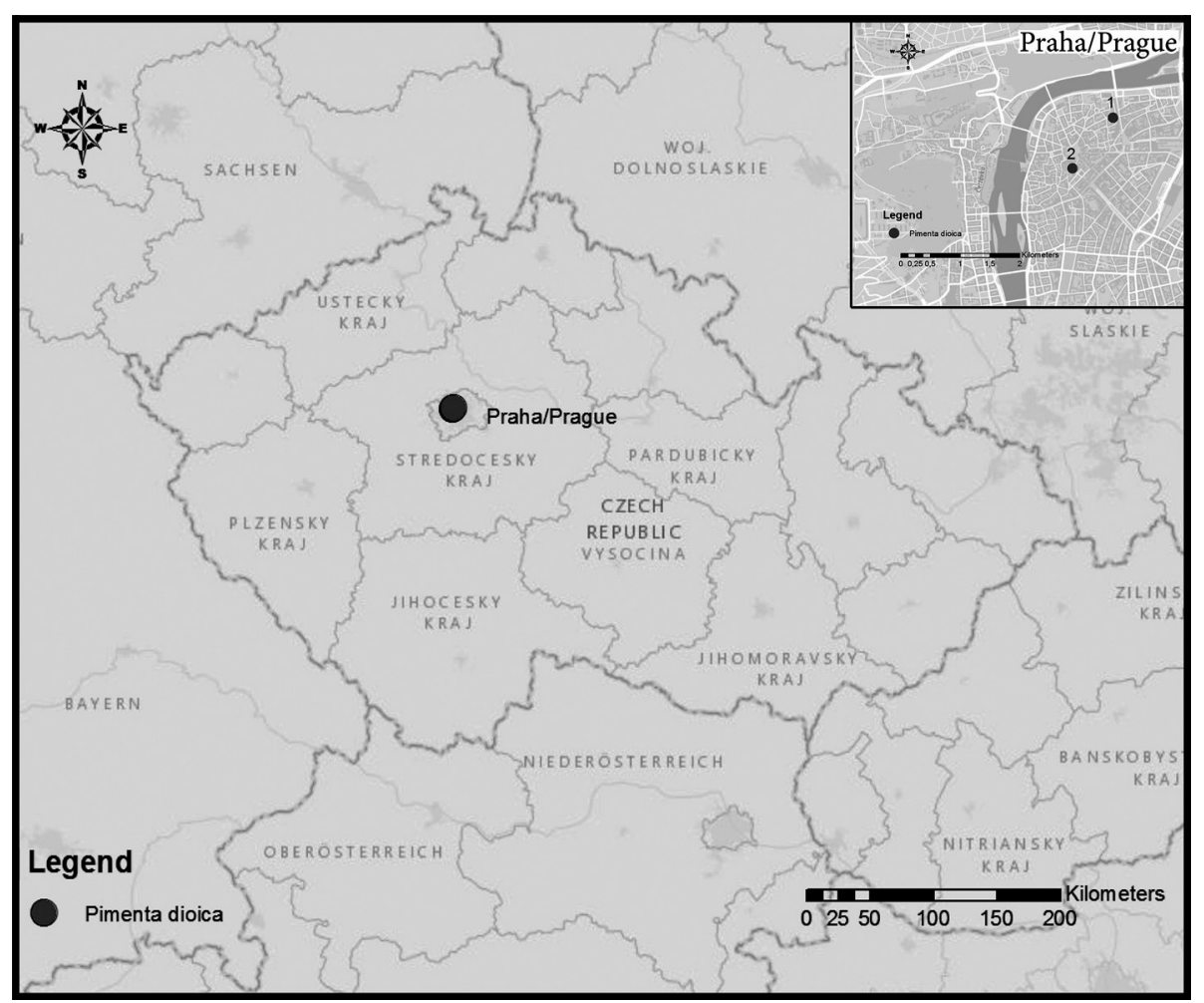

Figure 10. Map of archaeobotanical findings of Pimenta dioica in the Czech Republic and historical centre of Prague: 1. Melantrichova st.; 2. Dlouhá st., no. 721/I (M. Preusz). 


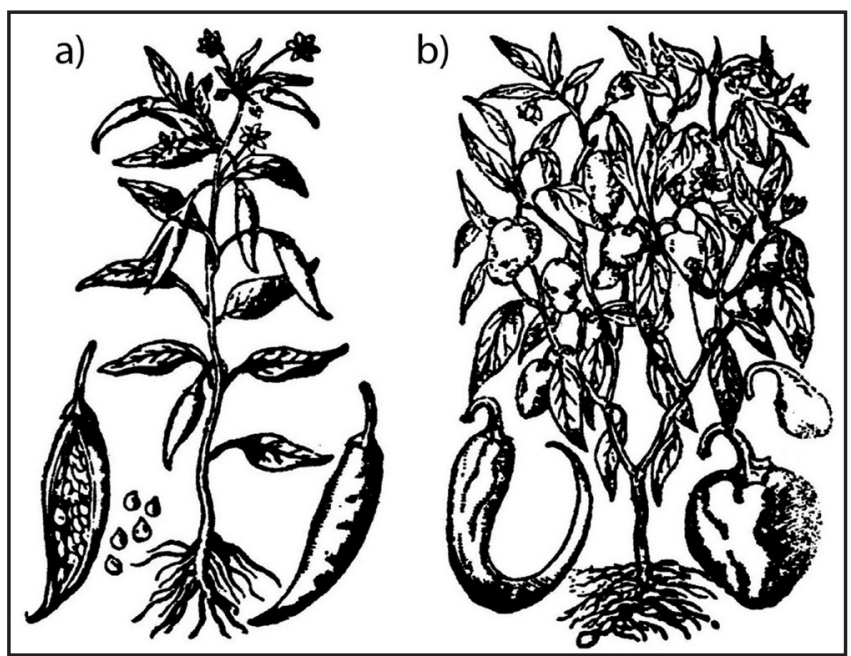

Figure 11. Imported peppers (Capsicum annuum) from the New World: a) “Turkish pepper"; b) "Indian pepper" (Mattioli 2005).

Kašperské Hory are dated to the $17^{\text {th }}-18^{\text {th }}$ century, the same as that of the largest collection of pepper seeds (over 400 seeds) from Uherský Brod.

\section{Exotic spices and the central European consumer society}

When interpreting information about archaeobotanical finds of exotic spices in the Czech Republic, our work has been aimed at describing the origin of taxa, their exploration by Europeans and subsequent transfer, or their primary reflections in herbariums. Only marginally have we mentioned the Medieval and Early Modern society that represented the final consumers of these rare commodities brought to them from afar.

The defining factor to which we must pay attention is the social context in which the archaeobotanical finds were recorded. It was exclusively the environment of higher social groups, the environment of the royal court, nobility and of the town - in which large groups of rich people were brought together. This was also the same environment where these people had the best possibilities to buy those exotic spices from trading merchants. The urban environment played an important role as an intermediary for trade with both domestic and exotic species, and also as an environment with a large consumer base.

For shopkeepers, the trade with spices was only one of many sources of income (Figure 13). It is not known whether or not there were any specialized dealers of spices in the Czech lands, similar to that recorded from other European countries. However, in the mid-14 ${ }^{\text {th }}$ century, the canon of the Prague Chapter, Magister Claretus, had spices registered that he had separated into two distinct groups (Flajšhans 1926, 1928). The first, "De radicibus", included pepper (perz), ginger (zazwor), cloves (hrzebiczek), cinnamon (skorzicze), licorice (lekoricze), anise (but), mace (muscatum kviet), caraway (kmyn) and saffron (ssafran). In the second group, "De frumento", were included domestic species, such as horseradish, hops, dill, and parsley. He clearly distinguished the luxurious spices, mostly of exotic origin, from the commonly available and inexpensive species. Only rich burghers could afford these expensive spices, as is reflected in the map of the distribution of exotic species in the major urban centres of Bohemia, Moravia and Silesia. By way of contrast, from Medieval and Early Modern contexts from

Figure 12. Map of archaeobotanical findings of Capsicum annuum in the Czech Republic and historical centre of Prague: 1. Thunovská st. no. 192/III (M. Preusz).

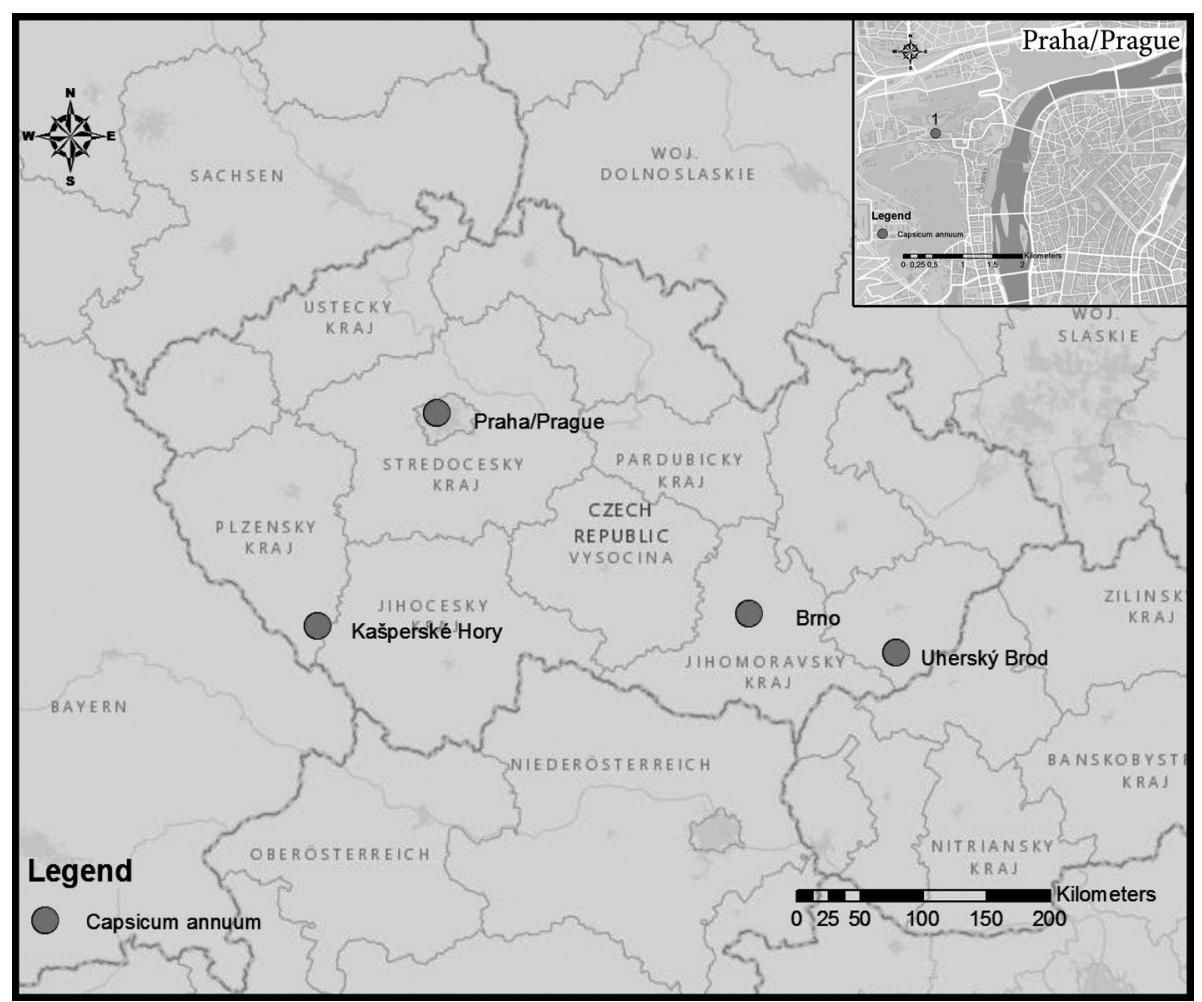




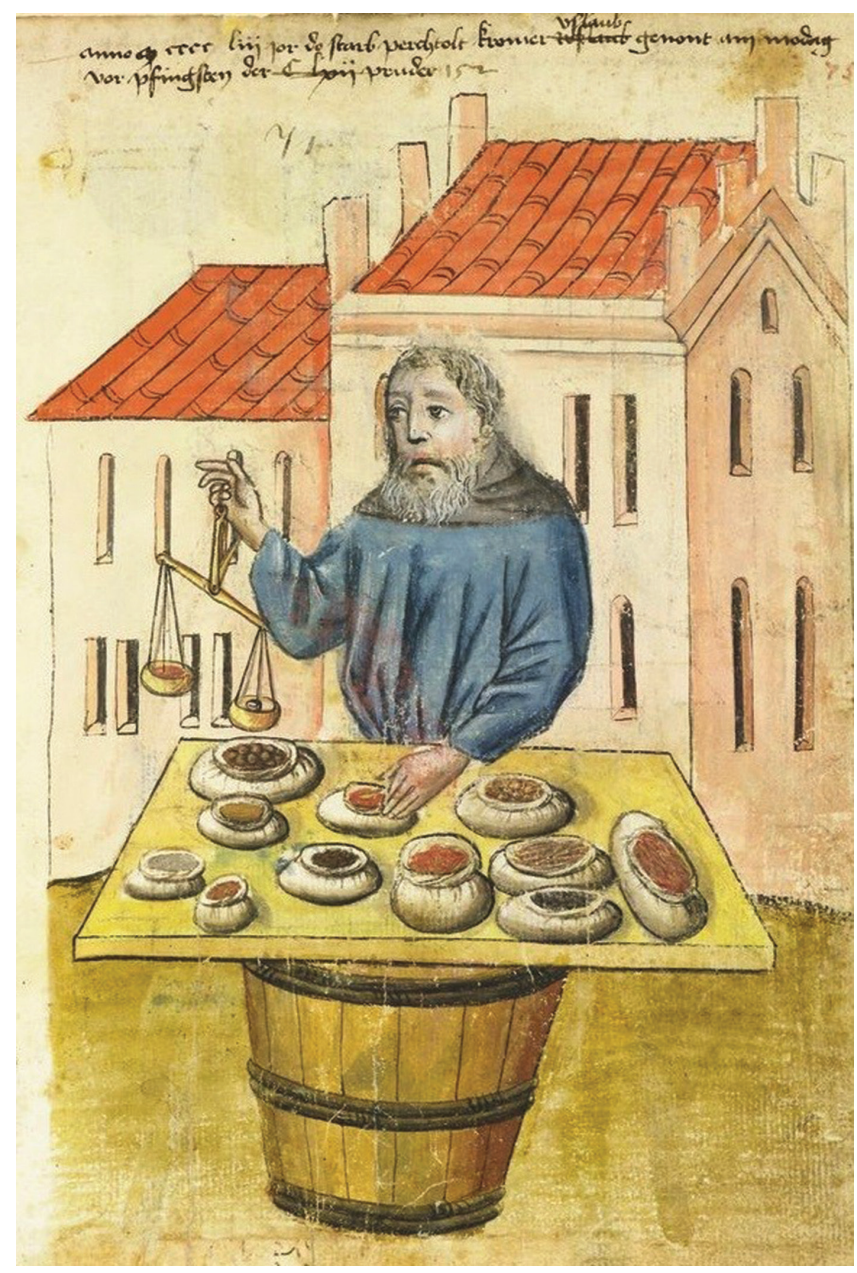

Figure 13. A merchant with spices in Nuremberg, Germany (Die Hausbücher der Nürnberger Zwölfbrüderstiftungen: http://www.nuernberger-hausbuecher.de/).

the environment of smaller towns, mostly domestic species are recorded, such as: chives (Allium schoenoprasum), caraway (Carum carvi), common hop (Humulus lupulus), common juniper (Juniperus communis), field mint (Mentha arvensis), horse mint (Mentha longifolia), and lemon thyme (Thymus pulegioides); or spices with their origin in the Mediterranean region, such as: dill (Anethum graveolens), celery (Apium graveolens), black mustard (Brassica nigra), coriander (Coriandrum sativum), saffron (Crocus sativus), fennel (Foeniculum vulgare), bay tree (Laurus nobilis), lavender (Lavandula angustifolia), cress (Lepidium sativum), marjoram (Majorana hortensis), lemon balm (Melissa officinalis), love-in-a-mist (Nigella damascenal sativa), oregano (Origanum vulgare), parsley (Petroselinum crispum), anise (Pimpinella anisum), rosemary (Rosmarinus officinalis), sage (Salvia officinalis), summer savory (Satureja hortensis), and thyme (Thymus vulgaris).

Other evidence of exotic spices comes from the aristocratic environment. Aristocrats possessed financial resources sufficient enough to acquire exotic materials as well as having the best overview of current events, particularly in connection with the news of the discovery of the New World spreading through central Europe. In this environment, exotic plants represented not only a symbol of luxury, but also a symbol of social superiority, which reflected a person's material and spiritual wealth. A good example is the portrait of the Emperor Rudolf II of Habsburg as Vertumnus: it is a symbol of the Renaissance monarch, a ruler over Nature; an exotic red pepper is evident in the detail of his costume (Figure 14).

In the Czech environment, the surroundings of Prague Castle and forecastle are exceptionally well-studied, and here can be found a large number of urban palaces of the nobility and high clergy (e.g. Čulíková 1998; 2001a; 2001b; 2007). A second example is from the research into the Royal Castle in Uherský Brod - where black pepper was discovered from a time before 1643 (Opravil 1974, 220-221).

Knowledge of spices in aristocratic environments is mostly dependent on archival studies. Archives can enrich our archaeobotanical knowledge in a unique way by giving insights into the mechanisms that Czech nobility used in the procurement and consumption of spices. Aristocratic mansions received spices by way of shopping, or paying in kind, and sometimes as a gift. Since spices were, together with meat, salt and wine, the most expensive and also most exotic commodity, they were usually bought abroad.

The main nation importing to central Europe in the $16^{\text {th }}$ century was Italy. The goods were then transported into the Danube region through a network of markets in various urban centres, ranging from the Romano-Germanic region, through

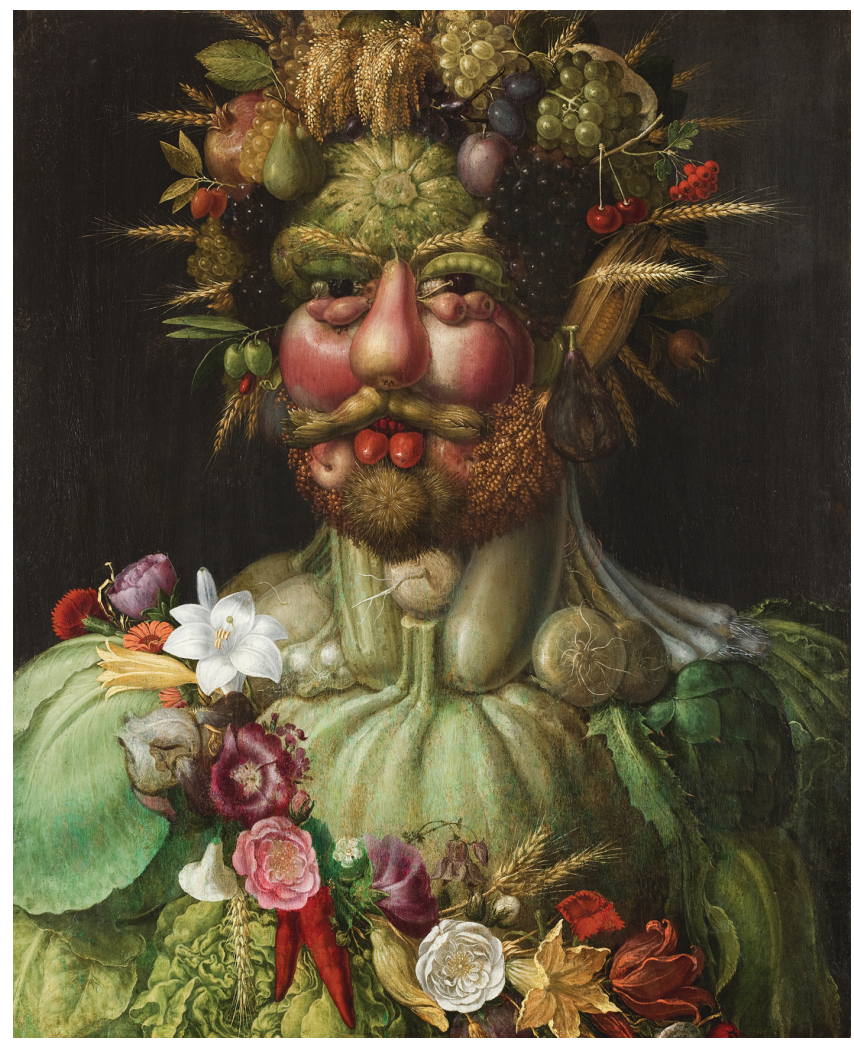

Figure 14. Pepper in a painting by Giuseppe Arcimboldo, Rudolph II of Habsburg as Vertumnus, 1590 (Skokloster Castle, Sweden). 
Austria and on to Hungary. Among the most important trade centres for Bohemia, Moravia and Silesia were the towns of Nuremberg, Linz, Krems, Vienna and Freistadt (Bůžek 1991, 237). Less important was the domestic market, especially in the provincial capitals of Prague (Janáček 1955, 74-110), and Brno. However, these markets also played their role, particularly in supplying urban residences; in these respects, the archaeobotanical data obtained from this environment correlate with historical reports.

The purchasing of supplies for manors, and similar large households pertaining to nobles, was the responsibility of selected civil clerks and purchasing officers, who in turn were under the supervision of the nobleman's wife. In the $16^{\text {th }}$ century, many clerks representing the most significant aristocratic families, such as the Lobkovicz, the Rabstejn, the Lords of Hradec, the Rosenbergs, the Sternbergs, the Kolovrats and others, travelled to the Danube region to purchase the required spices and other commodities. There they were buying saffron, ginger, black pepper and cubeb pepper, clove, cinnamon and mace from foreign countries. Archived receipts also put other commodities under the label "exotic goods" - raisins, Parmesan cheese, Nuremberg's ginger bread and such tropical fruit as oranges, limes, olives, almonds and pistachios. In contrast, common spices fell under the label (or on lists) of "kitchen equipment". The purchased spices were transported in large carriages and kept in large storerooms. When the court travelled to their country houses, they took the spices along with them, representing as it did such a luxurious commodity. In less important, smaller manors, the exotic spices were often replaced by domestic species, such as horseradish, caraway, anise and juniper (Hrdlička 2000).

According to records from the second half of the $16^{\text {th }}$ century from the castle of the Lords of Hradec in Jindřichův Hradec, spices used in the kitchen, on an annual basis, were: $10-25 \mathrm{~kg}$ of black pepper, 3-10 kg of saffron, $20 \mathrm{~kg}$ of clove, $25 \mathrm{~kg}$ of ginger and less than $10 \mathrm{~kg}$ of mace and cinnamon. Despite these high annual amounts, the recommendations in existence in kitchens were to use "spices moderately and only as necessity requires" [original Czech: "kořeni v mírnosti a jakž potřeba káže”](Hrdlička 2000).

Apart from markets, gardens were another source of spices, though mostly of domestic species. Since the second half of the $16^{\text {th }}$ century, seedlings of exotic plants could be bought. They usually have special cognomens ("additional names") that expressed their exotic origin, such as "Turkish", "Indian" and so on (Hrdlička 2000).

\section{Conclusion}

The current state of research of exotic spices suggests strong historical commercial ties between central Europe and overseas regions. Traditional ties to the Mediterranean region, that reach deep into prehistory, were in Ancient and
Medieval times supplemented by imports from Asia. The Indian Ocean, therefore, constituted the most important socio-economic environment of the time.

Only after the discovery of the New World was there a complete restructuring of European business interests as new, previously unknown, species of spices were discovered and quickly transported to the old continent, including central Europe. Thus, at the beginning of the $16^{\text {th }}$ century we can begin to think in terms of a global spice market that spanned the world. From this perspective, contemporary archaeobotany is extending our current, mostly artifactual, concept of historical archaeology through the study of ecofacts that were among the range of commercially traded goods and which played important roles during Europe's colonization of overseas areas by providing "exotic" supplies for the European consumer society.

In this context, local archaeobotanical finds of exotic spices not only represent a unique testimony of the development of global trade, but also the embracing of luxury goods in the domestic environment. Unfortunately, the current state of archaeobotanical knowledge is limited by the state of archaeological research as practiced today. Systematic attention is primarily devoted to the urban environment, with predominance for commercial research. Less attention is paid to the environment of villages and castles. Archaeological research into castles are under the administration of the National Heritage Institute (NHI), a body which still holds the traditional concept of artifactual archaeology without the use of modern environmental methods. As a result, the archaeobotanical view is restricted to the urban environment with only some exceptional detours into other social environments.

The aim of this paper was to present different kinds of exotic spices found from various archaeobotanical sets from the Middle Ages and the Early Modern period, to characterize their cultural and trade routes from overseas to central Europe, and to show the transformation of their consumption in different social environments. We have tried to summarize the development of research into exotic spices, to trace the range of species found in archaeological contexts, and for the first time to introduce all archaeobotanical finds of valuable exotic spices in the Czech lands. In the future there exists the open possibility to compare current data with data from the deeper past, or with data from the research of neighbouring countries, where similar research is in progress (see Livarda 2011).

\section{Acknowledgements}

This article was supported by the OPVK project PAPAVER - Centre for human and plant studies in Europe and Northern Africa in the post-glacial period, registration no. CZ.1.07/2.3.00/20.0289. This article was also supported by the GAJU 116/2013/P project - Bioarcheologie jižních Čech (2013-2015). 


\section{References}

ACKROYD, P. 2010: Benátky: přiběh nejromantičtějšiho města na Zemi. Praha. ADAMS, C. D. 1972: Flowering Plants of Jamaica. Mona.

ALSLEBEN, A. 1991: Archäobotanische Untersuchung in der Hansestadt Lübeck. Landschaftsentwicklung im städtischen Umfeld und Nahrungswirtschaft während des Mittelalters bis zur frühen Neuzeit. Offa 48, 329-362.

ALVES, J. S. F. 2011: The $16^{\text {th }}$ century Portuguese shipwreck of Oranjemund, Namibia. Report on the missions carried out by the Portuguese team in 2008 and 2009. Lisbon.

BADURA, M. 2003: Pimenta officinalis Lindl. (pimento, myrtle pepper) from early modern latrines in Gdańsk (northern Poland). Vegetation History and Archaeobotany 12/4, 249-252.

BADURA, M. 2011: Rośliny użytkowe $w$ dawnym Gdańsku. Studium archeobotaniczne. Gdańsk.

BENEŠ, J., KOČÁR, P., SUCHÁ, R. 1998: Doklady dálkových kontaktů ve středověké Evropě na základě studia vybraných archeobotanických nálezů. Archaeologia historica 23, 285-293.

BŮŽEK, V. 1991: Linecké trhy a kultura jihočeských měšt’anských domácností v předbělohorské době. In: Pánek, J. (Ed.): Česká města v 16. - 18. století. Praha, 237-244.

CASTRO, F. 2003: The Pepper Wreck, an early $17^{\text {th }}$-century Portuguese Indiamanat the mouth of the Tagus River, Portugal. The International Journal of Nautical Archaeology 32/1, 6-23.

CASTRO, F., FONSECA, N., WELLS, A. 2010: Outfitting the Pepper Wreck. Historical Archaeology 44/2, 14-34.

ČULÍKOVÁ, V. 1994: Nález zbytku plodu muškátovníku vonného (Myristica fragrans Houtt.) v Berouně. Archeologické rozhledy 96, 252-254.

ČULÍKOVÁ, V. 1998: Rostlinné makrozbytky $\mathrm{z}$ raně středověkých sedimentů na III. nádvoří Pražského hradu. Archaeologica Pragensia 14, 329-341.

ČULÍKOVÁ, V. 2001a: Rostlinné makrozbytky z lokality Praha 1 Malá Strana, Malostranské nám. čp. 258/III (Lichtenštejnský palác). Mediaevalia archaeologica 3, 137-166.

ČULÍKOVÁ, V. 2001b: Rostlinné makrozbytky z pěti středověkých lokalit př́i obvodu centrální části Pražského hradu. Mediaevalia archaeologica 3, 303-327.

ČULÍKOVÁ, V. 2007: Zpráva o prvním archeobotanickém nálezu líčidla amerického (Phytolacca americana L.) ve střední Evropě a o dalších druzích užitkových rostlin z Prahy - Hradčan. Archeologické rozhledy $59 / 2,353-370$

ČULÍKOVÁ, V. 2011: Pozdně středověké odpadní jímky na Drůbežím trhu v Opavě: pepř, kmín, cibule, černucha a další rostliny (archeologický výzkum v r. 2005). Časopis slezského muzea B 60/1, 1-46.

ČULÍKOVÁ, V. 2014: Moderní sortiment užitkových rostlin v barokové jímce v Thunovské ulici čp. 192 na Malé Straně v Praze. Staletá Praha 29/2, 64-119.

DAVIDSON, A. 2002: The Penguin Companion to Food. London.

DICKSON, C. 1996: Food, medicinal and other plants from $15^{\text {th }}$ century drains of Paisley Abbey, Scotland. Vegetation History and Archaeobotany $5,25-31$.

DOHNAL, Z. 1958: Užitkové rostliny a jejich upotřebení na slovanském hradišti v Klučově u Českého Brodu. Památky archeologické 49, 499-512.

FIETZ, A. 1941: Mikroskopische Untersuchung von drei mittelalterlichen Bauopfern aus Brünn. Verh. Naturforsch. Ver. Brünn 72, 62-70.

FLAJŠHANS, V. (ed.) 1926: Klaret a jeho družina. Sv. I: Slovníky veršované. Praha.

FLAJŠHANS, V. (ed.) 1928: Klaret a jeho družina. Sv. II: Texty glosované. Praha.

FLATMAN, J., STANIFORTH, M. 2006: Historical maritime archaeology. In: Hicks, D., Beaudry, M. C. (Eds.): Historical archaeology. Cambridge, $168-188$.

GIORGI, J. 1997: Diet in Late Medieval and Early Modern London: the archaeobotanical evidence. In: Gaimster, D., Stamper, P. (Eds.) The Age of Transition. The Archaeology of English Culture 1400-1600. Oxford, 197-213.

GREIG, J. 1996: Archaeobotanical and historical records compared - a new look at the taphonomy of edible and other useful plants from the $11^{\text {th }}$ to the $18^{\text {th }}$ centuries a.d. Circaea $12,211-247$.
HAJNALOVÁ, E. 1985: New palaeobotanical finds from Medieval towns in Slovakia. Slovenská Archeológia 33/2, 399-438.

HELLWIG, M. 1997: Plant remains from two cesspits $\left(15^{\text {th }}\right.$ and $16^{\text {th }}$ century) and a pond (13 ${ }^{\text {th }}$ century) from Göttingen, Southern Lower Saxony, Germany. Vegetation History and Archaeobotany 6/2, 105-116.

HRDLIČKA, J. 2000: Hodovní stůl a dvorská společnost. České Budějovice. JANÁČEK, J. 1955: Dějiny obchodu v predbělohorské Praze. Praha.

JEITTELES, L. H. 1872: Die vorgeschichtlichen Alterthümer der Stadt Olmütz und ihrer Umgebung II. Reste aus dem Pflanzenreich. Mittheilungen der anthro-pologischen Gesellschaft in Wien, 18-21.

JIRÁSEK, V. 1958: Rostliny na našem stole. Praha.

KARG, S. 2007: Medieval Food Traditions in Northern Europe. Copenhagen.

KAVINA, K. 1951: Speciálni botanika zemédělská. Rostliny prvoobalné. Praha.

KOČÁR, P., JANKOVSKÁ, V., STAREC, P., HUML, V. 2007: Paleoetnobotanická analýza novověkého antropogenního sedimentu Z Prahy, Melantrichovy ulice č.p. 465/1. Ve službách archeologie 2, 26-37. KOČÁR, P., KOČÁROVÁ, R. 2009: Archeobotanická analýza. In: Podliska, J., Cymbalak, T. 2009: Praha 1 - Malá Strana, Malostranské náměstí 11, čp. 260/III. Excavation report about archaeological excavation nr.: 2006/21 NPU UOP in Prague. Deposited: Archive of the Institute of Archaeology of the Czech Academy of Sciences in Prague nr. 713/10 nad Archive if the National Heritage Institute in Prague nr. 1218/10.

KOČÁR, P., SŮVOVÁ, Z., KOČÁROVÁ, R., KYNCL, L. 2007: Environmental analyses of the content of a Renaissance cesspit from Malá Strana in Prague. Studies in Post-Medieval Archeology 2, Praha, 383-400.

KOČÁROVÁ, R., SƯVOVÁ, Z., HAVRDA, J., KOČÁR, P. 2008: Změny na parcele domu č.p. 248 v Liliové ulici na Starém Městě pražském : výsledky bioarcheologického výzkumu. Ve službách archeologie 1, $171-188$.

KOSŇOVSKÁ, J. 2011: Archaeobotanical analysis of the waste-vault infill from Vladislav Hall, Prague castle. MS. Master diploma thesis. Deposited: Faculty of Science, University of South Bohemia, ČeskéBudějovice.

KYBAL, J., KAPLICKÁ, J. 1988: Naše a cizí koření. Praha.

LATAŁOWA, M., JAROSIŃSKA, J., BADURA, M. 1998: Elbląg średniowieczny w świetle dotychczasowych materiałów archeobotanicznych. Archeologia Polski 43, 147-166.

LIVARDA, A. 2011: Spicing up life in northwestern Europe: exotic food plants in the Roman and medieval world. Vegetation History and Archaebotany 20, 143-164.

LÜSSNER, M. 1859: Zpráva o starožitnostech nalezených r. 1858 v Králové Hradci. Památky Archeologické a mistopisné 3, 235-237.

LÜSSNER, M. 1865: Zpráva o starožitnostech nalezených v Chrudimi r. 1861 a 1863. Památky Archeologické a mistopisné 6, 114-116.

MATTIOLI, P. A. 2005: Herbář neboli bylinář I-III. Praha.

OPRAVIL, E. 1974: Zajímavý nález rostlinných pochutin a drog z poč. 17. stol. z Uherského Brodu. Český lid 61/4, 220-225.

OPRAVIL, E. 2002: Novověké archeobotanické nálezy z Uherského Brodu. Slovácko, 43, 107-114.

ORSER, CH. E., Jr. 2008: The Global and the Local in Modern-World Archaeology. In: Gelichi, S., Librenti, M. (Eds.): Constructing Post Medieval Archaeology in Italy: A New Agenda, Firenze, 25-33.

PAETZOLD, D, 1998: Einbeck, Negenbomer Weg. Paläoethnobotanische Untersuchungen. In: Heege, A. et al.: Einbeck - Negenborner Weg 1: Naturwissenschaftliche Studien zu einer Töpferei des 12. und frühen 13. Jahrhunderts in Niedersachsen. Keramiktechnologie, Palaeoethnobotanik, Pollenanalyse, Archëozoologie. Oldenburg, 89-168.

POLÍVKA, F. 1908: Užitkové a pamětihodné rostliny cizich zemí. Olomouc. PRABHAKARAN NAIR, K. P. 2011: Agronomy and Economy of Black Pepper and Cardamom : The "King” and "Queen" of Spices. Elsevier.

RZEHAK, A. 1904: Zur Kenntnis der sogenannten "Bauopfer". Mitteilungen der $k$. k. Zentral-Kommision für Erforschung und Erhaltung der Kunstund historischen Denkmale, Wien .3. F, 3. B. 452-454.

SMETÁNKA, Z., ŽEGKLITZ, J. 1990: Post-mediaeval Archaeology in Bohemia and its problems. Studies in Postmediaeval Archaeology 1, 7-21. ŠLÉZAR, P., ̌̌EŘICHOVÁ, Z., HENDRYCHOVÁ, L., SƯVOVÁ, Z. 2008: Environmentální nálezy z vrcholně středověké a raně novověké Litovle. Ve službách archeologie 2, 197-206. 
TICHÁ, Z. (ed.) 1975: Lékařské knižky Mistra Křištana z Prachatic. Praha. TOUSSAINT-SAMAT, M. 2008: A History of Food. New Jersey.

VAUGHAN, J. G., GEISSLER, C. A. 2009: The New Oxford Book of Food Plants. New York.

WIETHOLD, J. 1999: Pflanzenreste des Mittelalters und der frühen Neuzeit aus zwei Kloaken in der Hansestadt Rostock. Die Ausgrabungen Kröpeliner Straße 34-36/Kleiner Katthagen 4. Bodendenkmalpflege Mecklenburg-Vorpommen Jahrbuch 1998 46, 409-432.
WINTER, Z. 1892: Kulturni obraz českých měst v XV. A XVI. věku. Praha. WOLF, G. 1997: 3. Nutzpflanzen aus einer Kloake in Harm. Münden. Erste Ergebnisse der paläoethnobotanischen Untersuchung. In: Untersuchungen zu einer frühneuzeitlichen Kloake in Hannoversch. Münden, Landkreis Göttingen. Göttinger Jahrbuch 45, 13-53.

ZÍBRT, Č. 2011: Staročeské uměni kuchařské. Praha. 